\title{
Maternal serum ischemia modified albumin as a marker for hypertensive disorders of pregnancy: a pilot study
}

\author{
Sapna Vyakaranam ${ }^{1 *}$, Aparna Varma Bhongir ${ }^{1}$, Dakshayani Patlolla $^{1}$, Rekha Chintapally ${ }^{2}$
}

\author{
${ }^{1}$ Department of Biochemistry, Mediciti Institute of Medical Sciences, Ghanpur-501401, Medchal Mandal Ranga \\ Reddy, Telangana, India \\ ${ }^{2}$ Department of Gynaecology \& Obstetrics, Mediciti Institute of Medical Sciences, Ghanpur-501401, Medchal Mandal \\ Ranga Reddy, Telangana, India
}

Received: 04 March 2015

Accepted: 18 April 2015

\section{*Correspondence:}

Dr. Sapna Vyakaranam,

E-mail: sapna_vas@yahoo.co.in

Copyright: ( $\odot$ the author(s), publisher and licensee Medip Academy. This is an open-access article distributed under the terms of the Creative Commons Attribution Non-Commercial License, which permits unrestricted non-commercial use, distribution, and reproduction in any medium, provided the original work is properly cited.

\begin{abstract}
Background: Hypoxia driven oxidative stress of the placenta contributes to the pathogenesis of preeclampsia. Serum Ischemia Modified Albumin (IMA) has recently emerged as an oxidative stress marker, used in diagnosis of cardiac ischemia. Aim: To determine the efficiency of serum IMA in differentiating hypertensive disorders of pregnancy (pregnancy induced hypertension, preeclampsia) from normal pregnancy.

Methods: It was a case control study. Pregnant women $\geq 32$ weeks of gestation. Study population were included 3 groups, 19 Normotensive Pregnant (NP) women as controls, 18 pregnant women with Pregnancy Induced Hypertension (PIH) and 19 with preeclampsia (PE). Serum IMA was estimated by Enzyme Linked Immune Sorbent Assay (ELISA). Results were analyzed by student ' $t$ 'test. Critical values for serum IMA were obtained by Receiver Operation Characteristics (ROC) curves.

Results: Serum IMA levels were significantly elevated in PE $(56.84 \pm 21.57 \mathrm{ng} / \mathrm{ml})$ when compared with PIH (36.24 $\pm 14.51 \mathrm{ng} / \mathrm{ml})$ and $\mathrm{NP}(35.47 \pm 11.58 \mathrm{ng} / \mathrm{ml})(\mathrm{P}$ value $<0.001)$. With a cutoff of $38.33 \mathrm{ng} / \mathrm{ml}$, sensitivity and specificity for preeclampsia was $88.9 \%$ and $73.7 \%$ respectively.

Conclusions: Our study demonstrated that serum IMA, an oxidative stress marker is elevated in PE \& PIH. Hence serum IMA can undergo further evaluation as a marker of PE.
\end{abstract}

Keywords: Ischemia modified albumin, Pregnancy induced hypertension, Preeclampsia, Early marker

\section{INTRODUCTION}

Hypertensive disorders complicating pregnancy are common cause of the maternal morbidity and mortality. The spectrum includes pregnancy induced hypertension, preeclampsia, eclampsia. ${ }^{1}$ Though various studies have mentioned the etiopathogenesis of preeclampsia, even then it is regarded as "disease of theories".

The normal placental development in early pregnancy involves the plugging of spiral arteries with endovascular trophoblast. Defective endovascular trophoblastic invasion and inadequate remodeling of uterine spiral arteries cause vasoconstriction and vasoreactivity in placenta. $^{3}$ This causes hypoxic environment and generation of reactive oxygen species (ROS), leads to oxidative stress which is considered in the pathogenesis of preeclampsia. ${ }^{4,5}$

Serum Ischemia Modified Albumin (IMA) is recently been used as a serum biomarker for cardiac ischemia in acute coronary syndrome. ${ }^{6}$ The $\mathrm{N}$-terminus of albumin is altered in response to hypoxic environment and forms IMA. As hypoxia and oxidative stress are considered in 
etiopathogenesis of preeclampsia, serum IMA levels are also elevated in preeclampsia. ${ }^{7,8}$

Previous studies have mentioned elevated levels of serum IMA in preeclampsia when compared with normal pregnancy. ${ }^{9,10}$ Very few studies have demonstrated the correlation of serum IMA with severity of preeclampsia. $^{11,12}$ Contradiction to these studies also exists. ${ }^{13}$ All these studies were done in preeclampsia.

Hence the aim of our study is to determine maternal serum IMA and see if this marker can discriminate hypertensive disorders of pregnancy (Pregnancy induced hypertension, preeclampsia) from normal pregnancy.

\section{METHODS}

The present study included pregnant women aged 18-30 years and $\geq 32$ weeks of gestation attending the antenatal clinic in Obstetrics department. Institutional ethics committee clearance and written informed consent from participants were obtained.

Study population was divided into 3 groups. Eighteen women with Pregnancy Induced Hypertension (PIH) \& 19 women with preeclampsia (PE) were considered as cases. Control group included 19 normotensive women (NP).

PIH group included pregnant women with BP $\geq 140 / 90$ $\mathrm{mm}$ of $\mathrm{Hg}$ and without proteinuria.

PE group included pregnant women with $\mathrm{BP} \geq 140 / 90$ $\mathrm{mm}$ of $\mathrm{Hg}$ and with proteinuria given as $1+$ in dipstick or $\mathrm{Pr} / \mathrm{Cr}$ ratio as $\geq 0.3 \mathrm{mg} / \mathrm{gm}^{14}$

Cases and control groups were matched with age and gestational age. Pregnant women with bad obstetric history, twin pregnancy, previous pregnancy with hypertensive disorders, previous medical diseases like diabetes mellitus, essential hypertension, ischemic heart disease, peripheral vascular diseases were excluded from the study.

Blood pressure was measured with oscillometric digital sphygmomanometer (Omron HEM-780N3) on 2 separate occasions 4 hours apart and average was taken. Under strict aseptic conditions $5 \mathrm{ml}$ of blood sample was collected by venous puncture, into properly labeled plain polystyrene tubes. The samples were collected, handled and transported to the lab according to the guide lines given by clinical and laboratory standards institute/NCCLS (National Clinical Chemistry Laboratory Standards). ${ }^{15,16}$ Blood samples were centrifuged at $10000 \mathrm{rpm}$ for $10 \mathrm{~min}$ and the serum was collected in vials and stored at $-80^{\circ} \mathrm{C}$ till the analysis. Frozen samples were thawed to room temperature before analysis.
Serum IMA was estimated by human ischemia modified albumin, IMA ELISA Kit provided by WUHAN EIAAB science co. Ltd USCN LIFE on Dade Behring BEP 2000 version. Samples were added to Purified Human IMA coated antibody microtiter wells with biotin conjugated antibody preparation specific for IMA and avidin conjugated to Horse Radish Peroxidase (HRP) was added to microtiter plates and incubated. The TMB substrate was added to each well. Only those wells that contain IMA, biotin conjugated antibody and enzyme conjugated Avidin exhibited a color change. The enzyme substrate reaction was terminated by addition of sulphuric acid and color change was read at $450 \pm 2 \mathrm{~nm}$ spectrophotometrically with in $15 \mathrm{~min}$.

\section{Standardization of serum IMA estimation}

The working standard of IMA was reconstituted and diluted from aqueous stock solution of $500 \mathrm{ng} / \mathrm{ml}$ concentration. The stock standard was diluted to 7 different concentrations as, $500 \mathrm{ng} / \mathrm{ml}, 250 \mathrm{ng} / \mathrm{ml}, 125$ $\mathrm{ng} / \mathrm{ml}, 62.5 \mathrm{ng} / \mathrm{ml}, 31.2 \mathrm{ng} / \mathrm{ml}, 15.6 \mathrm{ng} / \mathrm{ml}, 7.8 \mathrm{ng} / \mathrm{ml}$ and the last tube with standard diluent was blank as $0 \mathrm{ng} / \mathrm{ml}$. A standard curve was created by generating a four parameter logistic curve fit (4-PL). The concentration of IMA in the samples was determined by comparing the O.D. of the samples to the standard curve.

The standard curve is represented in Figure 1.

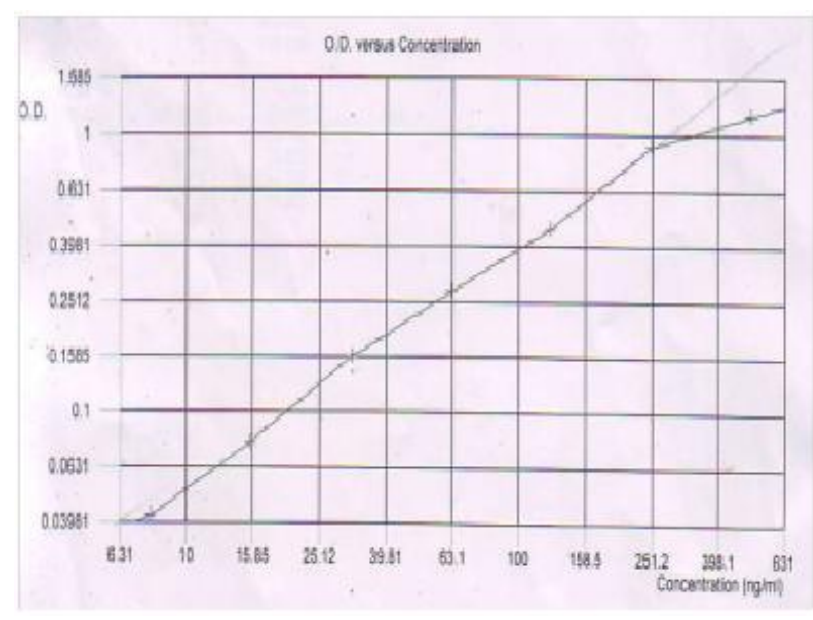

Figure 1: Standard curve of ischemia modified albumin (IMA) - Concentration on $\mathrm{X}$-axis \& absorbance (OD) on Y axis.

The assay range was $7.8 \mathrm{ng} / \mathrm{ml}-500 \mathrm{ng} / \mathrm{ml}$, the intra assay coefficient of variance (CV \%) was $6.7 \%$ with a standard of $62.5 \mathrm{ng} / \mathrm{ml}$.

Random midstream urine was collected for protein estimation. The samples were collected and transported according to the standard guidelines. ${ }^{17}$ Semi quantitative dip stick method was used to estimate the proteins. Two readings of $1+$ for samples at two different occasions were considered as diagnostic of preeclampsia. The 
pregnant women were followed till delivery for maternal outcome. Fetal birth weight was obtained on digital weigh scale (SECA 354/364).

\section{Statistical analysis}

The data was processed on MS excel work sheet. The results were analyzed by student' $t$ ' test and Chi square test. A 2-tailed probability value of 0.05 was considered as statistically significant. The critical values of IMA were obtained by Receiver Operation Characteristics (ROC) curves. All the statistical analysis were carried out using MedCalc Statistical Software version 12.7.8 (MedCalc Software bvba, Ostend, Belgium; http://www.medcalc.org; 2014.)

\section{RESULTS}

The study population included 19 Normotensive Pregnant women (NP), 18 women with Pregnancy Induced Hypertension (PIH), 19 women with preeclampsia (PE).

Demographic, clinical and biochemical characteristics in study population are represented in Table 1 .

Table 1: Demographic, clinical and biochemical characteristics in study population.

\begin{tabular}{|c|c|c|c|c|}
\hline & NP (19) & PIH (18) & PE (19) & P value \\
\hline Age (years) & $22.68 \pm 2.45$ & $21.67 \pm 2.09$ & $22.95 \pm 2.93$ & 0.27 \\
\hline Gestational age (weeks) & $36.26 \pm 4.34$ & $38.33 \pm 2.38$ & $36.21 \pm 2.59$ & 0.08 \\
\hline SBP (mm of Hg) & $112.63 \pm 7.33$ & $139.44 \pm 2.36$ & $147.89 \pm 9.76$ & $<0.001 *$ \\
\hline DBP (mm of Hg) & $73.16 \pm 7.49$ & $95 \pm 7.07$ & $101.58 \pm 11.67$ & $<0.001 *$ \\
\hline \multicolumn{5}{|l|}{ Urine proteins } \\
\hline Nil & 19 & 13 & Nil & \multirow{3}{*}{$<0.001 *$} \\
\hline Trace & Nil & 5 & 1 & \\
\hline$+/ 2+/ 3+$ & Nil & Nil & $5 / 8 / 5$ & \\
\hline Serum IMA (ng/ml) & $35.47 \pm 11.58$ & $36.24 \pm 14.51$ & $56.84 \pm 21.57$ & $<0.001^{*}$ \\
\hline
\end{tabular}

NP: Normotensive pregnancy; PIH: Pregnancy induced hypertension; PE: Preeclampsia *Significant $\mathrm{P}<0.05$

The mean age and gestational age were not statistically significant. There was a significant difference in Systolic Blood Pressure (SBP), Diastolic Blood Pressure (DBP) and urinary proteins among the groups.

The mean serum IMA levels in PE $(56.84 \pm 21.57 \mathrm{ng} / \mathrm{ml})$ were significantly elevated when compared with $\mathrm{PIH}$ $(36.24 \pm 14.51 \mathrm{ng} / \mathrm{ml})$ and normotensive pregnancy $(35.47 \pm 11.58 \mathrm{ng} / \mathrm{ml})$ with $\mathrm{P}$ value $<0.001$.

Table 2: Maternal and fetal outcomes in the study population.

\begin{tabular}{|c|c|c|c|c|}
\hline & NP (19) & PIH (18) & PE (19) & $\begin{array}{l}\mathbf{P} \\
\text { value }\end{array}$ \\
\hline \multicolumn{5}{|c|}{ Maternal outcome } \\
\hline VD & 14 & 8 & 3 & \multirow{3}{*}{$0.01 *$} \\
\hline LSCS & 5 & 10 & 15 & \\
\hline IUD & Nil & Nil & 1 & \\
\hline \multicolumn{5}{|c|}{ Fetal outcome } \\
\hline Term & 19 & 16 & 15 & \multirow{2}{*}{$0.03 *$} \\
\hline Preterm & Nil & 2 & 4 & \\
\hline $\begin{array}{l}\text { Birth } \\
\text { weight (Kg) }\end{array}$ & $2.82 \pm 0.03$ & $2.88 \pm 0.38$ & $2.47 \pm 0.51$ & $0.006^{*}$ \\
\hline
\end{tabular}

NP: Normotensive pregnancy; PIH: Pregnancy induced hypertension; PE: Preeclampsia; ${ }^{*}$ Significant $\mathrm{P}<0.05$
Maternal and fetal outcomes in the study population are represented in Table 2.

In NP group $74 \%$ of the women had Full Term Normal Vaginal Delivery (FTNVD) where as it was $44 \%$ and 16 $\%$ in PIH and PE groups respectively.

In NP group all the new born were full term whereas 2 of 18 in PIH and 4 of 19 in PE were preterm. The fetal birth weight was significantly low in PE group when compared with NP and PIH groups.

ROC analysis of serum IMA in hypertensive disorders of pregnancy are represented in Table 3.

Serum IMA with a cutoff of $38.33 \mathrm{ng} / \mathrm{ml}$ had greater sensitivity $(88.9 \%)$ and specificity $(73.7 \%)$ for preeclampsia than for PIH with a cutoff of $22.9 \mathrm{ng} / \mathrm{ml}$, sensitivity $(27.8 \%)$ and specificity $(89.5 \%)$.

Figure 2 and 3 - Represents the interactive dot diagram with cutoff, sensitivity and specificity of normal pregnancy with PIH and PE respectively.

Figure 4 - Represents comparison of ROC curves in PIH and preeclampsia. 
Table 3: ROC analysis of serum IMA in hypertensive disorders of pregnancy.

\begin{tabular}{|llllll|} 
& Cut-off & Sensitivity & Specificity & AUC & P of AUC \\
\hline $\mathrm{PIH}$ & $\leq 22.9$ & $27.8 \%$ & $89.5 \%$ & 0.50 & 0.95 \\
\hline $\mathrm{PE}$ & $>38.33$ & $88.9 \%$ & $73.7 \%$ & 0.81 & $<0.001 *$ \\
\hline
\end{tabular}

PIH: Pregnancy induced Hypertension, PE: Preeclampsia; AUC: Area under curve; *Significant P value $<0.05$

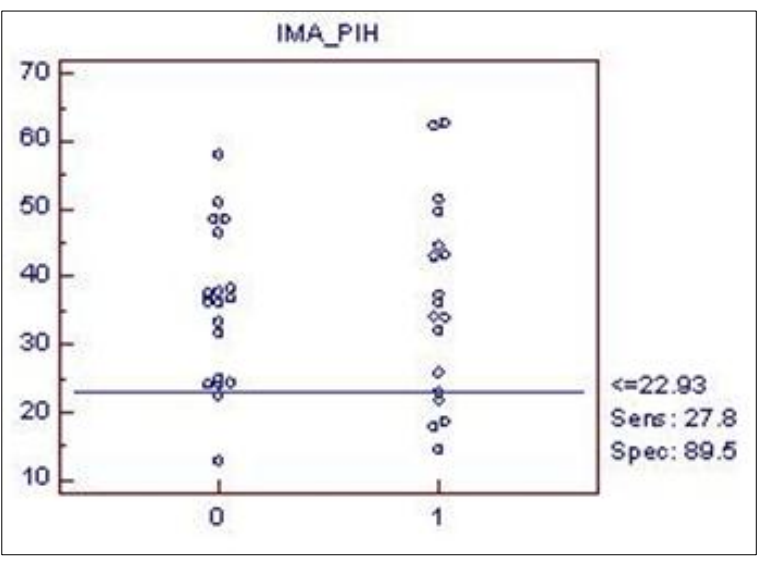

Figure 2: Dot diagram of serum IMA in normal pregnancy and PIH.

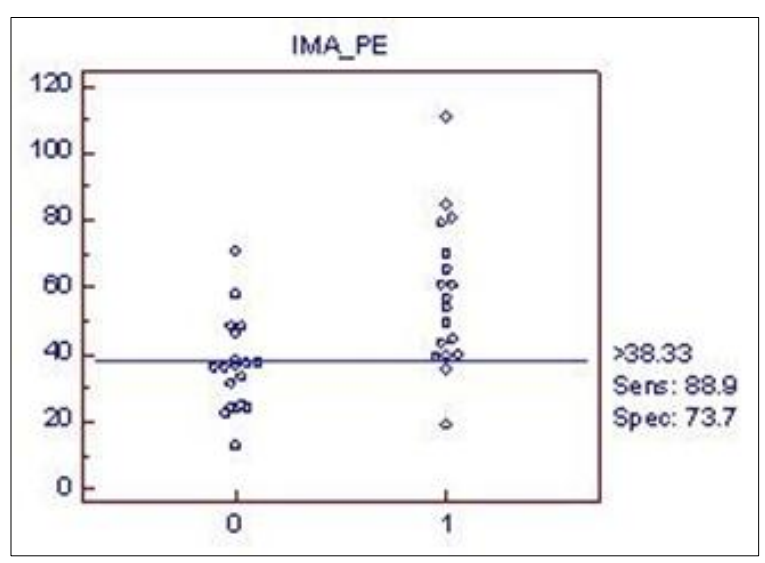

Figure 3: Dot diagram of serum IMA in normal pregnancy and PE.

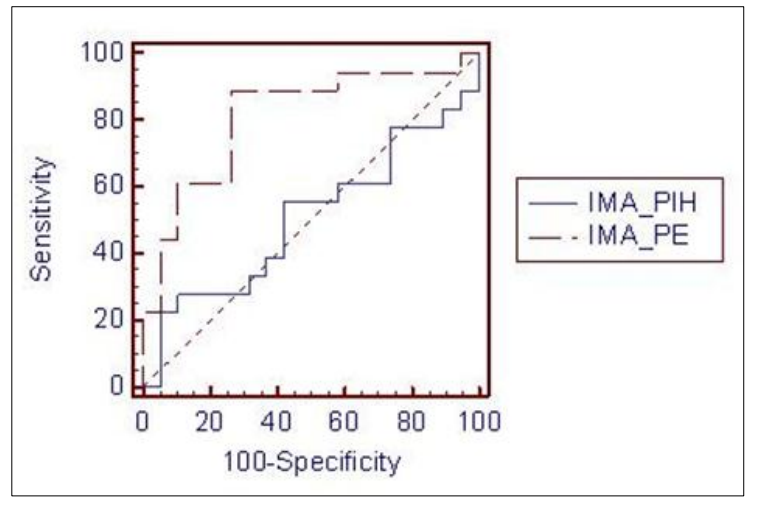

Figure 4: Comparison of ROC curves in PIH and PE.

\section{DISCUSSION}

In our study we observed elevated levels of serum Ischemia Modified Albumin (IMA) in preeclampsia when compared with PIH and normotensive pregnancy.

Serum IMA is formed in response to hypoxia or free radical injury to $\mathrm{N}$ terminus (asp-ala-his-lys) of albumin. ${ }^{18}$ It is been used as a marker of cardiac ischemia. Its levels are also elevated in conditions related to oxidative stress like scleroderma, end stage renal disease, peripheral vascular disorders and any events associated with hypoxia. ${ }^{19-21}$

Preeclampsia is characterized by poor placental perfusion due to vasospasm of uterine spiral arteries, which generate hypoxia and oxidative stress. ${ }^{22-24}$ Hence serum IMA a marker of oxidative stress and hypoxia is elevated in preeclampsia. Our study is in accordance with the studies done by Ustan Y et al., ${ }^{11}$ Gafsou et al., ${ }^{12}$ Jyothi et al. ${ }^{10}$ and Jyotirmayee et al. ${ }^{9}$ who observed elevated levels of serum IMA in preeclampsia in third trimester and Papageoghiour AT et al. ${ }^{3}$ who observed changes in first trimester.

Gafsou et al. ${ }^{12}$ studied non pregnant, normal pregnant and preeclampsia women at 30 weeks of gestation. A significant increase in serum IMA was observed in both pregnant and preeclamptic women when compared with non-pregnant women. The elevated levels of serum IMA continued till delivery. Jyotirmayee et al. ${ }^{9}$ and Jyothi et al. ${ }^{10}$ in their studies done on pregnant women at $30 \pm 4$ weeks and $34 \pm 4$ weeks of gestation respectively, found an elevated levels of serum IMA in preeclampsia.

Papageoghiour et al. $^{3}$ found an early elevation of serum IMA, i.e. at 11-12 weeks of gestation in women who later developed preeclampsia. It was stated that poor placental perfusion causes hypoxia and oxidative stress which leads to preeclampsia. These changes occur during the development of placenta. Hence serum IMA can be an early marker of preeclampsia.

In few studies increased serum IMA was attributed to the overproduction or decreased clearance. ${ }^{25}$ Though albuminuria is characteristic of preeclampsia, IMA was not present in the urine indicating an extra renal clearance. $^{26}$

In our study ROC curve analysis the cutoff $38.33 \mathrm{ng} / \mathrm{ml}$ resulted sensitivity and specificity of $88.9 \%$ and $73.7 \%$ 
respectively. Ustan $\mathrm{Y}$ et al. in his study observed that with a cutoff 0.31 ABU, serum IMA had $80 \%$ sensitivity and $77.8 \%$ specificity for preeclampsia.

In these studies serum IMA was estimated by an indirect method of albumin cobalt binding colorimetric assay (ACB) proposed by Bar-O et al. ${ }^{27}$ It is based on the principle that IMA loses its ability to bind to heavy metals like $\mathrm{Co}^{+2}$. In ACB method a known amount of cobalt was added to serum and the unbound cobalt was measured by the intensity of colored complex with dithiothreitol. IMA was expressed as U/ml. One IMA unit was defined as $\mu \mathrm{gm}$ of free Cobalt in the reaction mixture per $\mathrm{ml}$ of serum sample. This method would not give the concentration of serum IMA.

In our study we directly and quantitatively measured the serum IMA by ELISA method. The results obtained in our study are in accordance with the previous studies but the values cannot be compared due to the variation in the methodology.

This is the first study in which serum IMA in pregnant women was quantitatively estimated by ELISA method.

In conclusion serum IMA levels are elevated in preeclampsia which can be estimated quantitatively. Further studies focusing on serum IMA as an early marker of preeclampsia should be done to identify woman who may benefit from early intervention. Our study is limited by the sample size.

\section{ACKNOWLEDGEMENTS}

Research reported in this publication was conducted by scholars in the Fogarty international center of the national institutes of health training program under award number D43 TW 009078. The content is solely the responsibility of the authors and does not necessarily represent the official views of the national institutes of health.

We would like to thank Dr. P. S. Reddy, Chairman, Share India for constant support and providing the funds. Dr. Clareann H. Bunker, Associate professor, Graduate school of Pittsburg for editing the paper. We would like to thank Dr. P. Satyanarayana, HOD department of Lab Medicine, nursing staff of department of obstetrics and lab technicians for their support in collection and storage of samples.

Funding: The study was funded by SHARE INDIA, Mediciti Institute of Medical sciences

Conflict of interest: None declared

Ethical approval: The study was approved by the institutional ethics committee

\section{REFERENCES}

1. National High Blood Pressure Education Program Working Group. Report on high blood pressure in pregnancy. Am J Obstet Gynecol. 2000;183:S1-22.
2. Dekkar G, Sibai B. Etiology and pathogenesis of preeclampsia: current concepts. Am J Obstet Gynecol. 1998;179:1359-75.

3. Papageoghiour AT, Prefumo F, Leslie K, Gaze DC, Collinson PO, Thilaganathan B. Defective endovascular trophoblast invasion in first trimester is associated with increased maternal serum ischemia modified albumin. Hum Reprod. 2008;23(4):803-6.

4. Burton GJ, Jauniaux E. Placental oxidative stress: from miscarriage to preeclampsia. J Soc Gynaecol Invest. 2004;11:342-52.

5. Jauniaux E, Hempstock J, Greenwold N, Burton GJ. Trophoblastic oxidative stress in relation to temporal and regional differences in maternal placental blood flow in normal and abnormal early pregnancies. Am J Pathol. 2003;162:115-25.

6. Anwaruddin S, Januzzi JL Jr, Baggish, Lewandrowski EL, Lewandrowski KB. Ischemiamodified albumin improves the usefulness of standard cardiac biomarkers for the diagnosis of myocardial ischemia in the emergency department setting. Am J Clin Pathol. 2005;123:140-5.

7. Roberts JM. Preeclampsia: what we know and what we do not know? Semin Perinatol. 2000;24:24-48.

8. Uotila J, Solakivi J, Jaakkola T, Tumila O, Lehtimaki R. Antibodies against copper oxidized and malondialdehyde - modified low density lipoproteins in preeclampsia pregnancies. Br J Obstet Gynaecol. 1998;105:1113-7.

9. Bahinipati J, Mohapatra PC, Pradhan T. Role of maternal serum ischemia modified albumin as a biochemical marker in preeclampsia. Biomed Res. 2014;25(2):153-6.

10. D'souza JM, Pai VP, Harish S, Shriyan C, D'souza N. IMA and IMAR in serum and saliva of preeclampsia - a preliminary study. Hypertens Pregnancy. 2014 Nov;33(4):440-8.

11. Ustan Y, Ustun YE, Ozturk O, Alanbay I, Yaman H. Ischemia-modified albumin as an oxidative stress marker in preeclampsia. J Maternal-Fetal Neonatal Med. 2011;24(3):418-21.

12. Gafsou B, Lefevre G, Hennache B, Debarge VH, Bouthers A. Maternal serum ischemia modified albumin: a biomarker to distinguish between normal pregnancy and preeclampsia. Hypertens Pregnancy. 2010;29:101-11.

13. Rijn V, Franx A, Sikkema JM, Herman JM, Bruinse $\mathrm{H}$, Hieronymus Voorbij AM. Ischemia modified albumin in normal pregnancy and preeclampsia. Hypertens Pregnancy. 2008;27:159-67.

14. Brown AM, Lindheimer MD, de Swiet M, Van Assche A, Moutquin JM. The classification and diagnosis of the hypertensive disorders of pregnancy: statement from the International Society for the Study of Hypertension in Preeclampsia (ISSHP). Hypertens Pregnancy. 2001;20(1):9-14.

15. Procedures for the collection of diagnostic blood specimens by venipuncture. Approved Standard. 4th ed. Wayne PA: National committee for Clinical Laboratory Standards; 1998. 
16. Procedures for handling and transport of domestic diagnostic specimens and etiologic agents. Approved Standard. 3rd ed. Wayne PA: National committee for Clinical Laboratory Standards; 1994.

17. Urinanalysis and collection, transportation and preservation of urine specimens. Approved Guidelines. 2nd ed. National committee for Clinical Laboratory Standards GP-16A2. 2008;21(19):4-21.

18. Bar-Or D, Curtis G, Rao N, Bampos N, Lau E. Characterization of the $\mathrm{Co}(2+)$ and $\mathrm{Ni}(2+)$ binding amino acid residues of the $\mathrm{N}$-terminus of human albumin. An insight into the mechanism of a new assay for myocardial ischemia. Eur $\mathrm{J}$ Biochem. 2001;268:42-7.

19. Borderie D, Allanore Y, Meune C, Devaux JY, Ekindjian OG, Kahan A. High ischemia-modified albumin concentration reflects oxidative stress but not myocardial involvement in systemic sclerosis. Clin Chem. 2004;50:2190-3.

20. Sharma R, Gaze DC, Pellerin D, Mehta RL, Gregson $\mathrm{H}$, Streather $\mathrm{CP}$, et al. Ischemia-modified albumin predicts mortality in ESRD. Am J Kidney Dis. 2006;47:493-502.

21. Apple FS, Quist HE, Otto AP, Mathews WE, Murakami MM. Release characteristics of cardiac biomarkers and ischemia-modified albumin as measured by the albumin cobalt-binding test after a marathon race. Clin Chem. 2002;48:1097-100.
22. Bar-Or D, Rael LT, Bar-Or R, Slone DS, Mains CW, Rao NK, et al. The cobalt-albumin binding assay: insights into its mode of action. Clin Chim Acta. 2008;387:120-7.

23. Pijnenborg R, Vercruysse L, Hanssens M. The uterine spiral arteries in human pregnancy: facts and controversies. Placenta. 2006;27:939-58.

24. Dekker GA, Sibai BM. Etiology and pathogenesis of preeclampsia: current concepts. Am J Obstet Gynaecol. 1998;179:1359-75.

25. Clavant SP, Sastra SA, Osicka TM, Comper WD. The analysis and characterization of immunounreactive urinary albumin in healthy volunteers. Clin Biochem. 2006;39:143-51.

26. Bar-Or D, Lau E, Winkler JV. A novel assay for cobalt-albumin binding and its potential as a marker for myocardial ischemia - a preliminary report. $\mathrm{J}$ Emerg Med. 2000;19:311-5.

27. Khong TY, De Wolf F, Robertson WB, Brosen I. Inadequate maternal vascular response to placentation in pregnancies complicated by preeclampsia and by small for gestational age infants. Br J Obstet Gynaecol. 1986;93:1049-59.

DOI: $10.18203 / 2320-1770.1 j \mathrm{rcog} 20150061$

Cite this article as: Vyakaranam S, Bhongir AV, Patlolla D, Chintapally R. Maternal serum ischemia modified albumin as a marker for hypertensive disorders of pregnancy: a pilot study. Int J Reprod Contracept Obstet Gynecol 2015;4:611-6. 